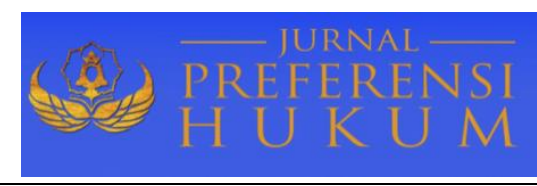

Jurnal Preferensi Hukum | ISSN: XXXX | E-ISSN: XXXX

Vol. 1, No. 2 - September 2020, Hal. 186-190| Available Online at https://www.ejournal.warmadewa.ac.id/index.php/juprehum

DOI: http://doi.org/10.22225/jph.v1i2.2386.186-190

\title{
TINDAK PIDANA PEMBUNUHAN YANG DILAKUKAN OLEH ANAK
}

\author{
Gede Widya Arsana, I Made Sepud, I Nyoman Sujana \\ Fakultas Hukum Universitas Warmadewa, Denpasar-Bali, Indonesia
}

\begin{abstract}
Abstrak
Siswa sekolah adalah generasi penerus yang masih membutuhkan pembinaan; Jika mereka gagal dibimbing maka akan terjadi pergolakan di dalam diri mereka yaitu kenakalan yang dapat berubah menjadi tindak kriminal, seperti pembunuhan. Latar belakang masalah di atas dirumuskan sebagai berikut: 1) Apa pertimbangan hakim dalam memutus kasus pembunuhan yang dilakukan oleh anak? 2) Bagaimana sanksi pidana yang dijatuhkan kepada seorang anak? Penellitian ini menggunakan metode penelitian hukum normatif. Hasil menunjukkan bahwa dasar pertimbangan hakim dalam menjatuhkan hukuman kepada remaja hanya berdasarkan tindakan kejahatan yang dilakukan oleh anak-anak. Para hakim hanya menjalankan kewajibannya berdasarkan UU yang telah ditetapkan dan yang menurut mereka putusan adil bagi masyarakat dan keluarga korban. Namun, majelis hakim tidak menganggap dampak negatif hukuman pidana 10 (sepuluh) tahun penjara yang dijatuhkan kepada anak-anak. Tampak jelas bahwa hakim cenderung menggunakan pertimbangan yuridis dalam pengambilan keputusan. Sementara mereka melakukannya, Nomort mempertimbangkan pertimbangan yuridis Nomorn dalam keputusan Nomor 22/Pid.Sus.Anak/2016/PN.Tjk yang sebetulnya harus didasarkan pada sosiologis, psikologis, crimiNomorlogical, dan filosofis dari remaja. Peneliti menyarankan agar: 1). Hakim harus mempertimbangkan dan mempertimbangkan kembali hukuman 10 tahun penjara yang dapat mengakibatkan penurunan mental pada anak karena masih tergolong relatif; 2) Para hakim harus mempertimbangkan kembali dampak yang akan terjadi pada anak-anak karena mereka hidup selama 10 tahun di penjara.
\end{abstract}

Kata Kunci: Anak; Pembunuhan; Putusan Hakim

\begin{abstract}
School students are the future generation who still need guidance; if they are failed to be guided, there will be an upheaval in their inner selves that is delinquency, which may turn into a criminal act, like murder. The backgrounds of problems are formulated as follows: 1). what is the judge's consideration in deciding cases of murder committed by the child? 2) How criminal sanctions are imposed on a child? This research uses normative legal research methods. The results show that the rationale judgment of the judges in imposing punishment to the juvenile was merely based on the action of crime committed by the children. The judges only perform their obligations under the Act that has been established and which they assume the verdict was fair for the society and the family victim. However, the judges failed to assume the negative impact of criminal penalties of 10 (ten) years of imprisonment sentenced to the children. It was clear that the judges tend to apply juridical considerations in decision making process. While they did consider the non-juridical considerations in decision Number 22/Pid.Sus.Anak/2016/PN.Tjk which actually should be based on sociological, psychological, criminological, and philosophical of the juveniles. The researcher suggests that: 1) The judges must consider and reconsider the punishment of 10 years imprisonment which may lead to mental decline in children because they are still relatively; 2) The judges shall reconsider the impact that would occur in children as they are living for 10 years in prison.
\end{abstract}

Keywords: Children; Murder; Verdict

\section{PENDAHULUAN}

Anak adalah suatu amanah yang diberi Tuhan ada dalam dirinya sebagai manusia sebenarnya (Wiyono, 2016). Anak itu sendiri telah memiliki kehormatan yang patut dihargai dan anak yang baru lahir harus mendapatkan atau menerima hak-haknya tanpa adanya tututan dari anak tersebut (Soekanto, 1992). Sesuai dengan hal ini ketentuan Kovensi Hak Anak adalah hal yang sudah disahkan undang-undang tentang anak, setelah dicantumkan di dalam UU kesejahteraan anak tentang 
Perlindungan Anak prinsip-prinsip umum yang mengemukakan semuanya perlindungan anak, Nomor diskriminasi, keperluan baik bagi anak, kesimanbungan hidup dan tumbuhkembang, dan menghormati partisipasi anak (Soeroso, 2014).

Keluarga adalah suatu sebab yang membuat anak melakukan penyimpangan, rumah anak berkembang di lingkungan sekolah dan lingkungan tempat bermainnya (Soekanto, 1992). Menyatakan, suatu lingkungan adalah institusi pendidikan kedua setelah keluarga (Gazali, 2013), oleh karena itu harus ada yang mencontrol di sekolah dan kita harus tahu siapa teman yang di ajak bermainnya, karna teman bermain juga dapat mempengaruhi anak.Tidak harus semuanya anak bersama tidak adanya keharomisan, selain membuat suatu pelanggaran hukum. Keluarga yang baik tidak bisa menjamin suatu anak yang membuat perilaku menyimpang (Soekanto, 1992), karena yang membuat sifat a n a k itu jelek ialah teman bermainnya. Kedudukan keluarga serta pendidikan anak sangat fundamental. Jika pendidikan keluarga gagal, anak akan melakukan tindakan kenakalan dalam lingkungan masyarkat dan tidak jarang menuju ke arah tindakan kriminal.

Perkembangan jaman di era modern ini dan pertumbuhan pada masyarakat cukup pesat, kejahatan selalu mendampingi di era modern ini dan kejahatan itu pula berkembang sangat pesat mengikuti laju perkembangan zaman pula. Kejahatan dengan senang hati ada dan terus mengikuti perubahan. Pengaruh zaman modern tidak dapat dielakkan, karena ilmu pengetahuan yang sangat mempengaruhi cara hidup manusia dan akhirnya manusia hanya bisa untuk berusaha meminimalisir jumlah kejahatan serta diikuti dengan membina penjahat tersebut secara efektif dan intensif.

Berdasarkan latar belakang penelitian di atas, peneliti membatasi masalah sebagai berikut 1 . Bagaimanakah pertimbangan hakim dalam memutus perkara tindak pidana pembunuhan yang dilakukan anak? 2. Bagaimanakah sanksi pidana pembunuhan yang dijatuhkan terhadap anak? Tujuan penelitian dari skripsi ini adalah sebagai berikut untuk mengetahui tindak pidana pembunuhan yang dilakukan oleh anak. Untuk mengetahui pertimbangan hakim dalam memutus perkara tindak pidana pembunuhan yang dilakukan anak.

\section{METODE PENELITIAN}

Dalam karya tulis yang bersifat ilmiah, tentu menggunakan metode untuk membahas permasalahan yang terjadi, tidak benar suatu karya ilmiah berdasarkan penafsiran belaka. Tujuannya tiada lain adalah agar karya tulis yg sifatnya ilmiah mempunyai persyaratan dan dapat dipertanggung jawabkan kebenarannya. Jenis metode penelitian yang digunakan dalam penelitian adalah penelitian hukum normatif yaitu dengan melakukan pengkajian berdasarkan bahan-bahan hukum dari literatur dan melakukan suatu proses untuk menemukan aturan hukum (Marzuki, 2009), prinsip hukum dan juga ketetapan hukum dalam tindak pidana yang dilakukan oleh Anak.

Adapun sumber bahan hukum yang akan digunakan yakni bersumber dari penelitian, keputusan, yaitu berupa: Bahan hukum primer yaitu bahan hukum dapat berupa peraturan perundangan (Muhammad, 2004) yakni: Undang-Undang Nomor 35 Tahun 2014 tentang Perlindungan Anak. Bahan hukum sekunder yaitu bahan hukum yang diperoleh dari pengkajian keputusan yaitu dengan membaca buku-buku hukum, jurnal-jurnal hukum, dan juga dari internet yg berkaitan dengan tindak pidana terhadap nyawa manusia yang dilakukan oleh anak sebagai permasalahan yang dibahas. Untuk memperoleh bahan-bahan hukum primer dan sekunder penulis melakukan penelitian dengan memakai teknik pengumpulan bahan dengan cara membaca buku-buku, peraturan perundangundangan serta literatur lainnya yang ada kaitan dengan permasalahan yang penulis bahas. Seluruh bahan-bahan yang sudah didapat dalam penulisan ini, selanjutnya dianalisis dan disusun secara sistematis dengan menggunakan argumentasi hukum.

\section{HASIL DAN PEMBAHASAN}

\section{Pertimbangan Hakim dalam Memutus Perkara Tindak Pidana Pembunuhan yang Dilakukan} Anak

Melihat suatu contoh kasus, pada zaman modern ini tidak bisa dipungkiri anak sudah berani melakukan tindak pidana pembunuhan. Contohnya, pelajar SMA di Bandar Lampung yang tega melakukan pembunuhan kepada pelajar SMA lain dan mengakibatkan terbunuhnya pelajar tersebut dengan 107 tusukan. Kejadian itu dilatar belakangi permasalahan asmara, dan karena perbuatannya pelaku dikenakan pasal 340 tentang Pembunuhan Berencana dan karena pelaku masih di bawah umur hukuman berpedoman pada Undang-Undang Nomor 11 Tahun 2012 tentang Sistem Peradilan Pidana 
Anak. Jika tindak pidana yang dilakukan anak merupakan tindak pidana yang diancam dengan pidana mati atau pidana penjara seumur hidup, pidana yang dijatuhkan adalah pidana penjara paling lama 10 tahun penjara (Wiyono, 2016).

Menurut sifatnya dilihat dari kejiwaan dari seorang anak yang masih di bawah umur, yang membuat anak itu bisa berbuat tindakan pidana adalah perkembangan jiwa yang masih labil mengenai persoalan asmara sehingga dia mempunyai tekanan batin dalam hati. Oleh karena itu seorang melakukan suatu tindakan yang sangat keji dan kejam.

Pemidanaan bertujuan hukum bukan hal yang baru di dunia hukum. Pemidanaan mempunyai dampak yang berkelanjutan di kehidupan terpidana (Soeroso, 2014), sehingga berakibat pada munculnya stigma yang ditunjukan kepada terpidana dan orang terdekatnya. Di dalam pidana dialirkan hukum pidana yang terbaru yang membuat suatu karangan pidana yang lebih memandang harga diri dan martabat manusia. Ini bertujuan untuk membentuk suatu hukum pidana itu sendiri agar menjadi lebih baik. Dipertimbangkan oleh hakim menjatuhkan hukuman pidana adalah suatu hal yang sangat penting, karena telah melibatkan keperluan-perluan tertentu. Undang-undang mengatakan kehakiman mempunyai pengaruh yang penting terhadap keputusan hakim sesuka hati memutuskan suatu perkara, tetapi Pasal 50 Undang-Undang Nomor 48 Tahun 2009 mengenai Wewenang Kehakiman menentukan hakim dalam memberi putusaan wajib memberi dasar-dasar putusan dan alasan-alasan selanjutnya di muat dengan pasal-pasal tertentu supaya bisa di jadikan dasar untuk mengadili suatu perkara.Pengertian anak UUNomor 35 Tahun 2014 Tentang Perlindungan Anak, yang dimaksud anak menurut Undang-Undang tersebut adalah seseorang yang belum berumur 18 (delapan belas) tahuntermasuk anak yang masih dalam kandungan.Atas dasar tersebut hakim menjatuhkan hukuman 10 (sepuluh) tahun penjara, sesuai dengan dakwaan jaksa berdasarkan ke-1 jo Undang-Undang Nomor 11 Tahun 2012 tentang Sistem peradilan pidana anak. Dari hasil analisa putusan Nomor: 22/PidanaKhususAnak/2016/PN.Tjk, hakim dalam menjatuhkan putusan yang bersifat yuridis mempertimbangkan dakwan dari Jasa Penuntut Umum, keterangan terdakwa, tindak pidana, barang bukti, keterangan saksi, dan Pasal di KUHP dan UU Sistem Peradilan Pidana Anak. Melainkan perbandinganNomor yuridis digunakan sebagai dasar pertimbangan untuk menjatuhkan putusan Nomor 22/PidanaKhususAnak/2016/PN.Tjk. Berdasarkan filosofis, sosiologis, psikologis kriminologis, anak tersebut tidak digunakan, karena perbuatan yang telah dilakukan anak tersebut sangat keji dan sadis, jika anak hanya dihukum 10 (sepuluh) tahun penjara dikhawatirkan bukannya anak tersebut menyadari kesalahannya melainkan anak tersebut dapat bertambah wawasannya mengenai perbuatan kriminal.

Berdasarkan Undang-Undang Negara Republik Indonesia Nomor 4 Tahun 1979 Tentang Kesejahteraan Anak pada BAB I ketentuan umum pasal (1) poin (2). Yang dimaksud anak adalah seseorang yang belum mencapai umur 21 (dua puluh satu) tahun dan yang belum kawin (Wiyono, 2016). Sedangkan pengertian anak menurut Pasal 1 ayat (5) Undang-Undang Nomor 39 Tahun1999 tentang Hak Asasi Manusia (HAM), anak adalah setiap manusia yang berusia di bawah 18 tahun dan belum menikah, termasuk anak yang masih dalam kandungan, apabila hal tersebut adalah demi kepentingannya meskipun banyak rumusan mengenai batasan dan pengertian anak, namun pada prinsipnya perbedaan tersbut mempunyai implikasi yang sama yaitu memberikan perlindungan pada anak. Dari itu, tindakan kejahatan yang dapat menghilangkan nyawa dapat dikatakan kejahatan atau kriminal yang mengenaidari kehidupan Orang. Ada beberapa aspek mengenai kejahatan terhadap nyawa yaitu, sebagai berikut:

Jika dilihat dari KUHP, kejahatan termasuk kejahatan kepada jiwa manusia atau seseorang, kejahatan terhadap jiwa yang dilakukan oleh anak di bawah umur atau bisa disebut anak baru lahir. Kejahatan terhadap anak yang masih di kandungan atau dalam janin seorang ibu. Berdasarkan bagian atau faktor kesengajaan (dolus) mengenai teori kehendak (wilsiheorie) merupakan kejahatan merupakan kesengajaan alam hal terwujudnya perbuatan atau tindakan (Kalia, 2013; Erlandi, 2018). Menurut ilmuwan tindakan sengaja merupakan kemauan untuk mengusahakan agar mengetahui unsur yang terdapat dan telah disusun terlebih dahulu, mewujudkan kemauan atau menyarankan seseorang untuk melakukan tindak pembunuhan diri diri sendiri. Suatu tindak kriminal itu didasari atas dilakukannya perbuatan secara sengaja, dilakukannya perbuatan secara sengaja dengan unsur pemberat, dan dilakukannya perbuatan secara terencana.

Dalam suatu hal pembunuhan, ada beberapa teori yang dikeluarkan oleh para ahli, yaitu: Teori Equivalensi yang diterapkan oleh Van Hammel bisa disebut dengan teori (conditio Sin Qua Non) 
yang bisa di katakan bahwa faktor yang mengakibatkan suatu akibat adalah sama (tidak ada unsur pemberat), dan Teori adequate yang diterapkan oleh Van Kriese atau lebih diketahui dengan teori keseimbangan, yang dinyatakan bahwa perilaku itu seimbang dengan akibat (ada alasan pemberat) (Subianto, 2013).

Teori Individualis dan Generalis dari T. Trager yaitu bahwa aspek yang condong paling memastikan akibat itulah yang menimbulkan. Sementara, menurut teori nyawa atau generalisasi aspek yang menimbulkan itu akibatnya harus dipisahkan satu persatu. Kriminal dalam bentuk pembunuhan dalam KUHP dapat dibedakan atau dikelompokkan atas 2 dasar, yaitu: unsur kesalahan dan unsur objek. Dasar kesalahan bertepatan dengan tindak pidana pembunuhan adalah pada kesalahan dan lain-lain. Atas dasar obyeknya (nyawa atau kepentingan hukum yang dilindungi), maka kejahatan terhadap nyawa dengan sengaja dibedakan dalam 3 macam, yaitu: kejahatan terhadap janin, kejahatan sesudah lahir, dan kejahatan saat jadi bayi. Kriminal pembunuhan ini disebut dengan delik materiil, yang merupakan delik yang bisa disebut sebagai suatu akibat yang timbul tanpa menyebut cara untuk bisa menimbulkan dari sebuah akibat tersebut. Perbuatan dalam pembunuhan terhadap nyawa dapat berwujud menembak dengan senjata, api, menikam dengan pisau, memberikan racun dalam makanan, bahkan dapat berupa diam saja dalam hal seseorang berwajib bertindak seperti tidak memberikan makan kepada seorang bayi.

Terjadinya perbuatan pidana materiil bukan hanya harus pada telah selesainya perbuatan dan apakah benar dari bentuk perbuatan tersebut telah menghasilkan dampak negatif yang telah dilarang atau tidak boleh dilakukan. Jika perbuatan itu tdak bisa membuat meninggalnya seseorang, ini merupakan kejadian percobaan pembunuhan, dan belum atau bukan pembunuhan secara sempurna sebagaimana dimaksudkan dalam Pasal 338. Jika dilihat dari cara merumuskannya, ada 2 ( $\mathrm{d}$ u a ) macam tindak pidana materiil, yakni suatu tindak pidana materiil yang tidak dengan formil merumuskan suatu akibat yang dilarang tersebut, melainkan yang sudah tersirat dengan sendirinya dari unsur suatu tindakan pidana. Tindak pidana materil yang dalam rumusannya mencantumkan unsur perbuatan atau tingkah laku. Hal ini juga disebut sebagai unsur akibat dari perbuatan (akibat konstitutif), misalnya pada penipuan (Pasal 378). Menurut UU SPPA (Sistem Peradilan Pidana Anak), ada dua jenis sanksi yang diberikan atas tindak pidana anak, antara lain, bagi yang berumur di bawah 14 tahun yang melakukan tindakan pidana dan bagi pelaku yang berumur 15 tahun ke atas yang melakukan tindak pidana.

\section{Sanksi Pidana Pembunuhan yang Dijatuhkan terhadap Anak}

Sanksi yang dapat dikenakan kepada anak meliputi pengembalian kepada orang tua atau wali, penyerahan kepada seseorang, perawatan di rumah sakit jiwa, kewajiban mengikuti pendidikan formal dan atau pelatihan yang diadakan oleh pemerintah atau badan swasta, dan perbaikan akibat tindak pidana. Sanksi pidana yang dapat dikenakan kepada pelaku tindak pidana anak terbagi atas pidana pokok dan pidana tambahan. Pidana pokok meliputi pidana peringatan, pidana dengan syarat yang terdiri atas pembinaan di luar lembaga, pelayanan masyarakat, atau pengawasan, pelatihan kerja, pembinaan dalam lembaga; penjara pidana tambahan: mengambil keuntungan yang didapat dari tindak pidana; atau pemenuhan kewajiban adat (Wiyono, 2016). Undang-undang SPPA juga dapat mengatur dalam hal anak belum berumur 12 (dua belas) tahun tetapi melakukan atau diduga melakukan tindak pidana. Penyidik, pembimbing kemasyarakatan, dan pekerja sosial profesional mengambil keputusan untuk: (1) menyerahkan kembali kepada orang tua atau wali, atau (2) mengikut-sertakannya dalam program pendidikan, pembinaan, dan pembimbing di instansi pemerintah atau LPKS di instansi yang menangani bidan kesejahteraan sosial, baik di tingkat pusat maupun daerah, paling lama 6 (enam) bulan (Wiyono, 2016).

Penyebab terjadinya tindak pidana pembunuhan adalah kehidupan di dalam masyarakat yang sangat berkembang dan sangat mempengaruhi berbagai masalah sosial dengan bukti kehidupan manusia zaman sekarang yang semakin susah dan pada akhirnya membuat masyarakat menimbulkan penyimpangan dalam tingkah laku. Keadaan membuat susah di hadapi, lalu orang melakukan melanggar norma-norma yang berlaku dan berbuat sesuka hatinya sendiri untuk mencapai kepuasaan dan kepentingan sendiri tanpa memperhatikan hak yang lainnya,; semua adalah unsur yang bersumber dari pribadinya.

Hal tersebut bisa tercermin dari ciri-ciri kepribadian itu sendiri. Seandainya keimanan kepada Tuhan Yang Maha Esa tumbuh terus dan di dalam keluarga pendidikan termasuk pendidikan 
formal memadai kejahatan dapat terlimitasi (Subianto, 2013). Dari faktor ekonomi, di lihat dari pengamatan peneliti, terjadinya sebagian besar pembunuhan itu disebabkan dari pergaulan dan kondisi ekonomi yang tidak menentu menimbulkan kemarahan. Faktor lingkungan lebih condong dari faktor pribadi dan faktor ekonomi yang memicu orang untuk melakukan pembunuhan. Ada sebagian contoh yang menguasai faktor lingkungan antara sekitar keluarga atau rumah tangga. Lingkungan keluarga didasari oleh aturan yang mendekat kepada Tuhan semestinya tidak sama oleh keluarga yang tidak dianjurkan ajaran agamanya serta keluarganya, sehingga tidak dapat dekat dengan ajaran agamanya tentunya akan mempengaruhi anak keturunannya di kemudian hari.

\section{SIMPULAN}

\section{Simpulan}

Simpulan penelitian ini ialah sebagai berikut:

1. Pertimbangan Hakim dalam memutuskan tindak pidana yang dilakukan oleh anak atau pelajar dapat diputuskan berdasarkan KUHP jo Ayat (1) ke-1 KUHP jo UU Nomor 11 Tahun 2012 tentang Sistem Peradilan Pidana Anak. Anak diancam dengan hukuman pidana penjara maksimal 10 (sepuluh) tahun penjara. Namun disisi lain hakim tidak memikirkan dampak negatif apa yang akan terjadi dari hukuman pidana 10 (sepuluh) tahun penjara yang telah diberikan kepada anak karena anak tersebut masih tergolong di bawah umur.

2. Sanksi tindak pidana pembunuhan yang dilakukan oleh dapat berupa peringatan pidana, syarat pidana yang terdiri atas di luar lembaga diberi pembinaan masyarakat atau pengawasan dan latihan kerja dan di dalam lembaga diberi pembinaan dan hukuman penjara.

\section{Saran}

Hakim harus memperhatikan dan mempertimbangan kembali pemberian atau pengambilan suatu keputusan atas tindakan pembunuhan yang dilakukan oleh anak yang masih di bawah umur karena masalah tentang anak itu sangat susah dan sangat bahaya kalau tidak ditanggani dengan serius, terutama untuk masa depan si anak bersangkutan.

\section{DAFTAR PUSTAKA}

Erlandi, G. A. (2018). Penyelesaian Perkara Tindak Pidana Terkait Penghinaan Agama. JuristDiction, 1(2), 537-556.

Gazali, M. (2013). Optimalisasi Peran Lembaga Pendidikan untuk Mencerdaskan Bangsa. Jurnal AlTa'dib, 6(1), 1689-1699.

Kalia, H. (2013). Pembuktian Tindak Pidana dengan Terang-Terangan dan Tenaga Bersama Menggunakan Kekerasan terhadap Orang yang Mengakibatkan Luka-Luka (Studi Putusan Nomor: 256/PID.B/2010/PN.DGL). Jurnal Ilmu Hukum Legal Opinion, 1(4), 1-9.

Marzuki, P. M. (2009). Penelitian Hukum. Kencana Prenada Media Group.

Muhammad, A. (2004). Hukum dan Penelitian Hukum (Pertama). Citra Aditya Bhakti.

Soekanto, S. (1992). Intisari Hukum Keluarga. Citra Aditya Bakti.

Soeroso, R. (2014). Perbandingan Hukum Perdata. Sinar Grafika.

Subianto, J. (2013). Peran Keluarga, Sekolah, dan Masyarakat dalam Pembentukan Karakter Berkualitas. Edukasia: Jurnal Penelitian Pendidikan Islam: Jurnal Penelitian Pendidikan Islam, 8(2), 331-354.

Wiyono, R. (2016). Sistem Peradilan Pidana Anak di Indonesia. Sinar Grafika. 